\title{
New Porphyrazinoid Containing Pyrazine in Place of One Pyrrole Ring
}

\author{
Aleksej V. Kozlov and Pavel A. Stuzhin ${ }^{\circledR}$ \\ Dedicated to Professor Oscar Iosifovich Koifman on the Occasion of his $70^{\text {th }}$ Anniversary \\ Research Institute of Macroheterocycles, Ivanovo State University of Chemical Technology, RF-153000 Ivanovo, Russia \\ ${ }^{\circledR}$ Corresponding author E-mail: stuzhin@isuct.ru
}

Vicinal diaminoporphyrazine $2 \boldsymbol{a}$ obtained by deselenation of hexa(4-tert-butylphenyl)-1,2,5-selenadiazoloporphyrazinatomagnesium(II) 1 a was oxidized with air oxygen to seco-porphyrazinedicarboxamide 3 a which upon acid treatment is converted to 2-oxy-4-aminopyraziniporphyrazine $\mathbf{4 b}$ - porphyrazine analogue containing pyrazine in place of one pyrrole ring.

Keywords: Diaminoporphyrazine, seco-porphyrazine, dicarboxamide, pyraziniporphyrazine.

\section{Новый порфиразиноиА с пиразиновым фрагментом вместо одного из пиррольных колец}

\author{
А. В. Козлов, П. А. Стужин ${ }^{@}$ \\ Посвящается Член-корреспонденту РАН Оскару Иосифовичу Койфману \\ по случаю его 70-летнего юбилея
}

\begin{abstract}
НИИ Макрогетероциклических соединений, Ивановский государственный химико-технологический университет, 153000 Иваново, Россия

@E-mail: stuzhin@isuct.ru
\end{abstract}

\begin{abstract}
При окислении кислородом воздуха вищинального диаминопорфиразина 2a, полученного при деселенировании гекса(4-трет-бутилфенил)-1,2,5-селенадиазолопорфиразинатомагния(II) 1a, образуется секо-порфиразиндикарбоксамид 3a, превращуающийся при действии кислоты в 2-оксо-4-аминопиразинипорфиразин $4 \boldsymbol{b}$ - новый порфиразиноид, в котором одно из пиррольных колец замещено на пиразиновый фрагмент.
\end{abstract}

Ключевые слова: Диаминопорфиразин, секо-порфиразин, дикарбоксамид, пиразинипорфиразин.

Porphyrazines containing fused 1,2,5-selenadiazole ring(s) can be easily deselenated upon treatment with $\mathrm{H}_{2} \mathrm{~S}$ in pyridine solution with formation of vicinal aminoporphyrazines, ${ }^{[1]}$ which can be used directly for preparation of various peripherally functionalized species e.g. porphyrazines with fused pyrazine $\operatorname{ring}(\mathrm{s})^{[1]}$ or attached formamide groups, ${ }^{[2]}$ Schiff-base porphyrazines and their metal complexes. ${ }^{[3]}$ In these works diaminoporphyrazine derivatives were obtained only in solution and used directly for further modifications. Recently we have studied the deselenation hexa(4-tert-butylphenyl)-1,2,5-selenadiazoloporphyrazines 1a,b. ${ }^{[4]}$ Diaminoporphyrazines $\mathbf{2 a , b}$ were obtained in solution but our attempts to isolate them in solid form failed due to some side reactions. We have supposed that this can be connected with oxidation processes, similarly as it was reported ${ }^{[5]}$ for bis(dialkylamino)porphyrazines oxidizing by air oxygen to seco-porphyrazine derivatives due to scission of the electron-rich $\mathrm{C}=\mathrm{C}$ double bond between two vicinal $\mathrm{NAlk}_{2}$ groups.

In order to verify this hypothesis we have dissolved the $\mathrm{Mg}^{\mathrm{II}}$ complex 1,2,5-selenadiazoloporphyrazine $\mathbf{1 a}^{[4]}$ (50 $\mathrm{mg}, 40 \mu \mathrm{M}$ ) in $50 \mathrm{ml}$ of deaerated pyridine and bubbled dry $\mathrm{H}_{2} \mathrm{~S}$ to achieve its complete conversion to $\mathrm{Mg}^{\mathrm{II}}$ diaminoporphyrazine 2a. Its UV-Vis spectrum contains a broad 


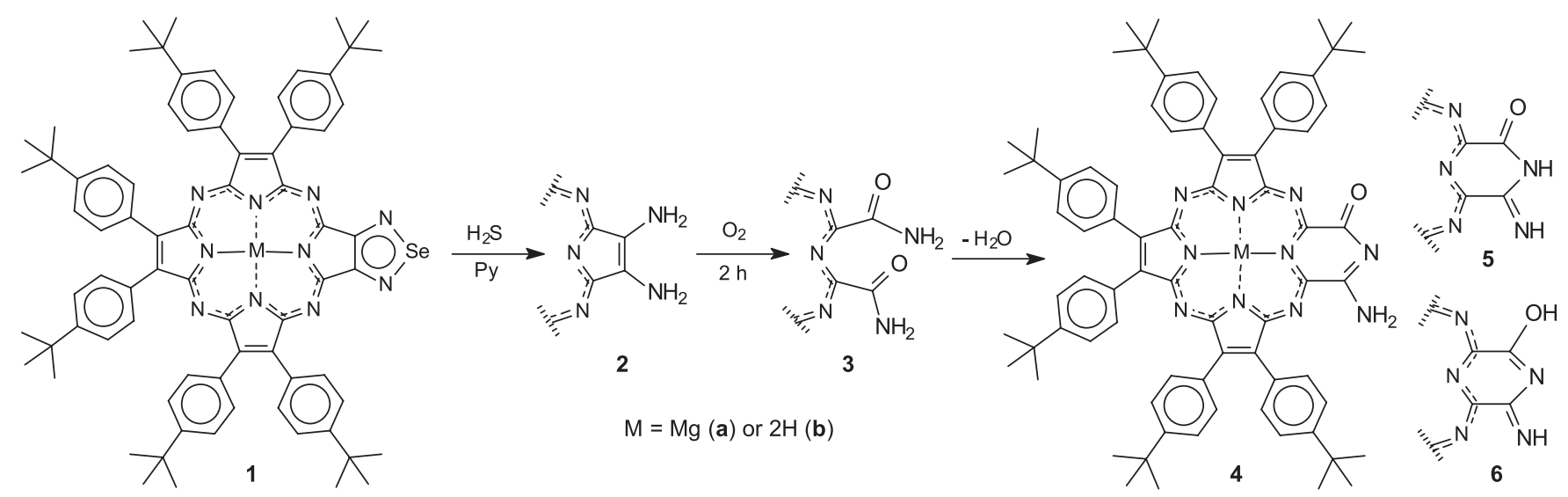

Scheme 1.

$Q$-band with maximum at $649 \mathrm{~nm}$ (Figure 1, curve 1 ) instead of the initial narrow $Q$-bands at 614 and $683 \mathrm{~nm}$ typical for 1a. ${ }^{[4]}$ After that argon was passed through the solution to eliminate residual $\mathrm{H}_{2} \mathrm{~S}$ and then air was bubbled for $2 \mathrm{~h}$. Oxidation by air oxygen led to disappearance of the broad band of diaminoporphyrazine at $649 \mathrm{~nm}$ and to growth of the new absorption bands at 583, 688 and $726 \mathrm{~nm}$ (Figure 1, curve 2). The absorption bands at 688 and $726 \mathrm{~nm}$ in the UV-Vis spectrum belong evidently to two different species, but we were unable to separate them using chromatography.

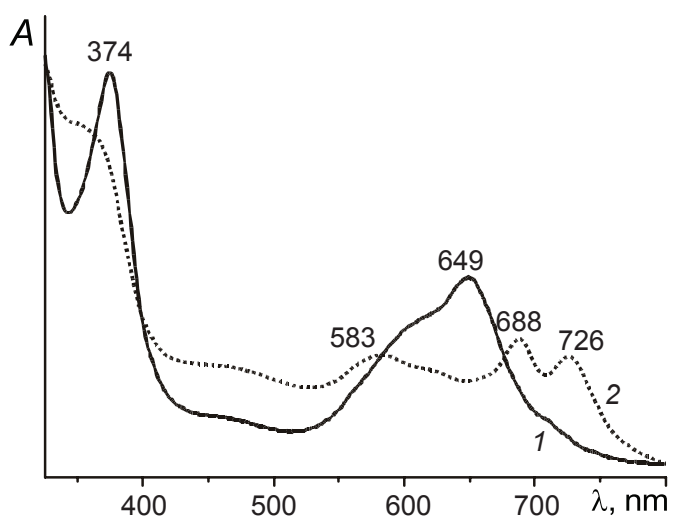

Figure 1. UV-Vis spectra of $\mathrm{Mg}^{\mathrm{II}}$ diaminoporphyrazine 2a in pyridine (1) and products of its oxidation by air oxygen (2).

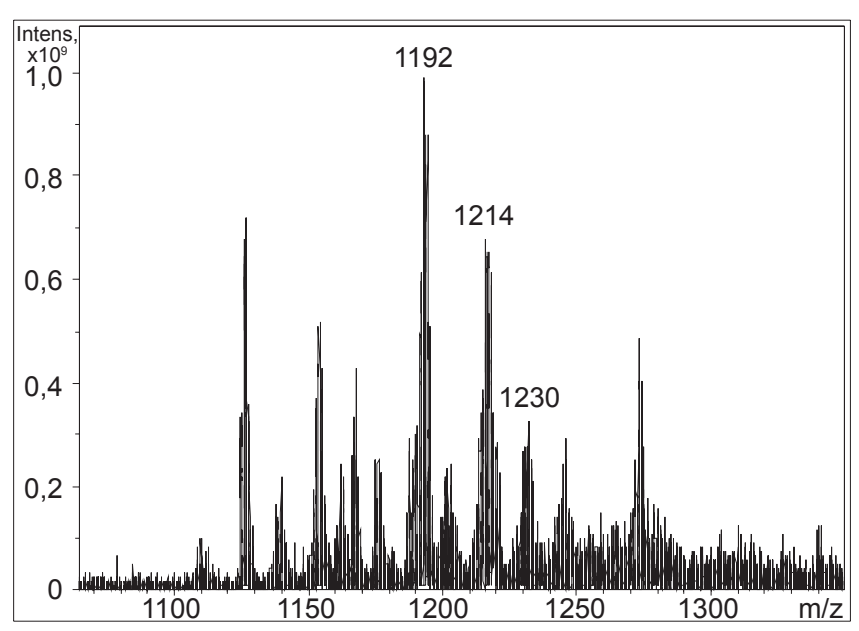

Figure 2. MALDI-TOF mass-spectrum of the reaction mixture obtained after oxidation of $\mathbf{2 a}$.
The MALDI-TOF mass-spectrum of the reaction mixture contains a number of peaks in the 1100-1300 Da region (Figure 2). The most intense peaks correspond to the molecular ions of the oxidized product $-\mathrm{Mg}^{\mathrm{II}}$ complex of secoporphyrazinedicarboxamide 3a $\left(\mathrm{m} / \mathrm{z}=1192[\mathrm{M}+\mathrm{H}]^{+}\right.$, $\left.1214[\mathrm{M}+\mathrm{Na}]^{+}, 1230[\mathrm{M}+\mathrm{K}]^{+}\right)$.

Difficulties in separation of $\mathrm{Mg}^{\mathrm{II}}$ porphyrazines is a common problem ${ }^{[6]}$ arising from their tendency to aggregation due to intermolecular $\mathrm{H}$-bonding between coordinated water in one molecule and $\mathrm{N}$ - or O-donor centers in another. Since metal free porphyrazines can be often more easily chromatographically separated, we have demetallated the reaction mixture obtained after oxidation by treatment with $\mathrm{CF}_{3} \mathrm{COOH}$ in $\mathrm{CH}_{2} \mathrm{Cl}_{2}$ and using gradual column chromatography on $\mathrm{Al}_{2} \mathrm{O}_{3}$ with $\mathrm{CHCl}_{3}-\mathrm{MeOH}$ have obtained the product $\mathbf{4 b}$ as a main fraction. ${ }^{\S}$ Its MALDI-TOF mass-spectrum contains a single peak of the molecular ion with $m / z=1151$ (Figure 3). This value is less by $18 \mathrm{Da}$ than expected for metal-free seco-porphyrazinedicarboxamide 3b $(m / z=1169)$ indicating that it belongs to a dehydration

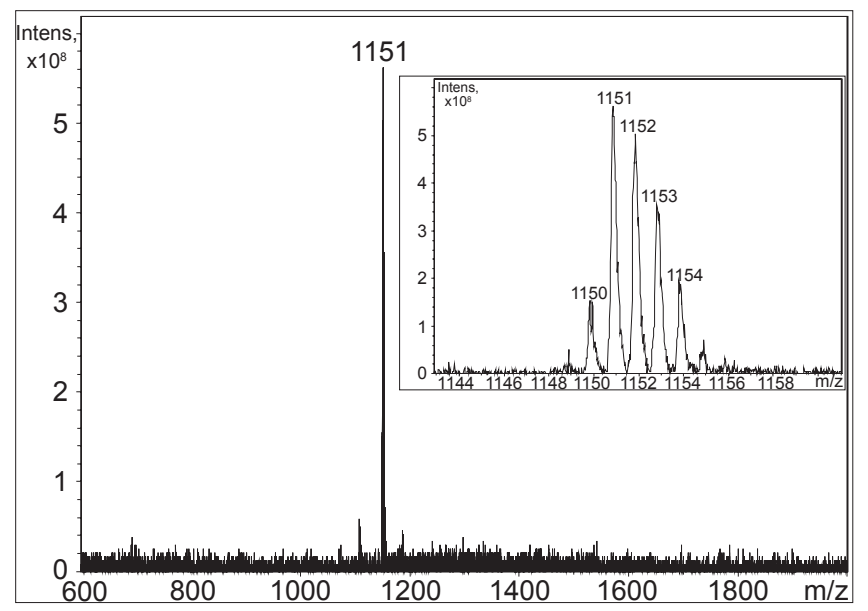

Figure 3. MALDI-TOF mass-spectrum of pyraziniporphyrazine $\mathbf{4 b}$.

${ }^{\S}$ Yield $32 \% . R=0.67\left(\mathrm{CH}_{2} \mathrm{Cl}_{2}\right)$. MALDI-TOF MS $m / z=1151[\mathrm{M}]^{+}$ (calcd for $\left.\mathrm{C}_{76} \mathrm{H}_{82} \mathrm{~N}_{10} \mathrm{O}-1150.67\right)$. ${ }^{1} \mathrm{H}$ NMR $\left(\mathrm{CDCl}_{3}\right) \delta$ ppm: 8.38 (m, 8H), 8.29 (d, 4H), 7.77 (d, 4H), 7.64 (d, 8H), 3.67 (s, 2H), $1.55(\mathrm{~d}, 36 \mathrm{H}), 1.43(\mathrm{~s}, 18 \mathrm{H}),-1.39(\mathrm{~s}, 2 \mathrm{H}) . \mathrm{UV}-\mathrm{Vis}\left(\mathrm{CH}_{2} \mathrm{Cl}_{2}\right) \lambda_{\text {max }}$ $\mathrm{nm}: 357,586,646,677 \mathrm{sh}, 713$. IR (KBr) $v \mathrm{~cm}^{-1}: 3221,2923,2855$, 1732, 1661, 1460, 1373, 1257, 1192, 1126, 1097, 972, 725, 604. 
product. Indeed, two neghbouring carboxamide groups in 3 can undergo dehydration, especially easy in the acidic conditions, with closure of 6-member ring and formation of cyclic iminoimide of secoporphyrazinedicarboxylic acid for which three tautomeric forms 4-6 are possible.

The DFT calculations (B3LYP/6-31G* basis set) indicate that the tautomer $\mathbf{4 b}$ containing 6-amino-2pyrazinone unit is by more that $12 \mathrm{kcal} / \mathrm{mol}$ more stable than alternative imidoimide $\mathbf{5 b}$ or 2-imino-6-pyrazinol $\mathbf{6 b}$.

The ${ }^{1} \mathrm{H}$ NMR spectrum in $\mathrm{CDCl}_{3}$ is consistent with structure $\mathbf{4 b}$ and contains along with signals of six 4-tertbutylphenyl groups in the aromatic and aliphatic regions (8.4-8.3 , 7.8-7.6 and $1.55,1.43 \mathrm{ppm})$ the broad signal of two internal $\mathrm{NH}$ groups in the high field (-1.39 ppm) and singlet of the $\mathrm{NH}_{2}$ group at $3.67 \mathrm{ppm}$. The IR bands observed at 3221,1732 and $1661 \mathrm{~cm}^{-1}$ are also in agreement with the presence of the 6-membered ring with a $\mathrm{NH}_{2}-\mathrm{C}=\mathrm{N}-\mathrm{C}=\mathrm{O}$ fragment.

Porphyrin analogues in which one of the pyrrole rings is substituted by 6-membered heterocycle are known ${ }^{[7]}$ and named, e.g. as benziporphyrins or pyriporphyrins for the species containing benzene or pyridine rings, respectively. Therefore, the obtained porphyrazine analogue with pyrazine fragment instead of one pyrrole ring can be named as pyraziniporphyrazine derivative (unlike pyrazinoporphyrazines contaning fused pyrazine ring(s)). So far among corresponding porphyrazine derivatives only phthalocyanine analogues were reported (so called three-quarter phthalocyanines) in which one of the isoindole ring is substituted by benzene or pyridine ring. ${ }^{[8,9]}$ It is noteworthy that the presence of highly aromatic benzene or pyridine ring instead of one of the pyrrole or isoindole unit interupts the $18 \pi$-electron conjugation in the internal 16-membered macrocycle making it non-aromatic. As a result the resonance of the internal NH protons in such molecules as benziporphyrins ${ }^{[10]}$ is observed in the low field region ( $c a$. 9-10 ppm) unlike common porphyrins showing this resonance in the high field $(-1 \div-4 \mathrm{ppm})$ due to strong shielding effect of the aromatic macrocycle. Non-metallated three-quarter phthalocyanines containing bridging benzene or pyridine ring (benzi- and pyriphthalocyanines) are very unstable and exhibit no absorption bands above $550 \mathrm{~nm} \cdot .^{[9,11]}$

The resonance of the internal $\mathrm{NH}$ protons in the obtained pyraziniporphyrazine $\mathbf{4 b}$ is observed in the strong

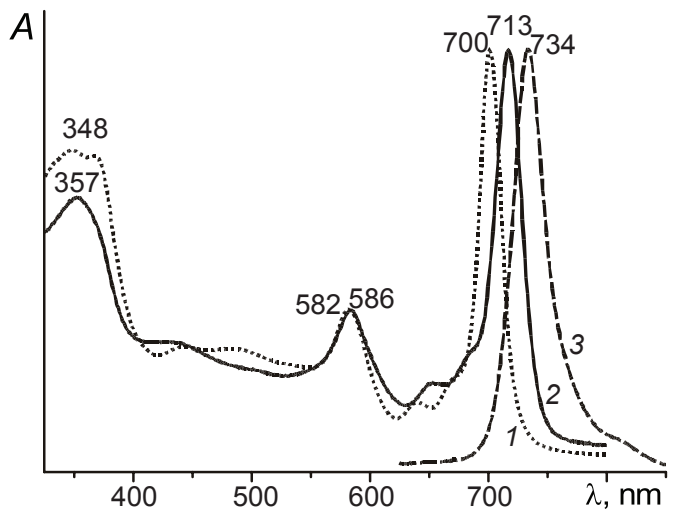

Figure 4. UV-Vis spectra of porphyrazine $\mathbf{1 b}(1)$ and pyraziniporphyrazine $4 \mathbf{b}(2)$ and fluorescence spectrum of $4 \mathbf{b}$ (3). field $(-1.39 \mathrm{ppm})$ indicating that aromaticity of the internal 16 -membered macrocycle is retained and is similar with that observed for the corresponding non-metallated 1,2,5selenadiazoloporphyrazine $\mathbf{1 b}\left(\delta_{\mathrm{NH}}=-1.56 \mathrm{ppm}\right) .{ }^{[4]}$ The high aromaticity of the internal macrocycle in $\mathbf{4 b}$ is explained by non-aromatic character of the pyrazine unit, which is in fact 2,3-dihydro-2-pyrazinone system. For structurally similar 2-oxybenzi- and 2-oxypyriporphyrins the $\mathrm{NH}$ resonances were also observed in the high field indicating the aromatic character of the macrocycle. ${ }^{[7]}$

Interestingly that UV-Vis spectra of non-metallated pyraziniporphyrazine $\mathbf{4 b}$ and 1,2,5-selenadiazoloporphyrazine 1b are similar (Figure 4) and differ only by bathochromic shift of the Soret band (by $8 \mathrm{~nm}$ ) and the long-wave component of the $Q$-band (by $13 \mathrm{~nm}$ ). Usually for secoporphyrazine derivatives the value of the bathochromic shift is much larger. Thus, for bis $(N, N$-dimethylcarboxamide) of hexapropylsecoporphyrazine the bathochromic shift of the $Q$-band is $c a$. $40 \mathrm{~nm}$ as compared to the corresponding 1,2,5-selenadiazole derivative. ${ }^{[5]}$ The theoretical calculations accomplished for the model species without tert-butyl groups by ZINDO/S method (Figure 5) also indicate that the spectra of pyraziniporphyrazine 4 should be similar in position of the $Q$-band to the spectra of corresponding porphyrazines, while a bathochromic shift is expected for the $Q_{\mathrm{x}}$ component in the case of seco-porphyrazine derivative 3 . The Q-bands at 726 and $688 \mathrm{~nm}$ in the UV-Vis spectrum obtained after oxidation of the $\mathrm{Mg}^{\mathrm{II}}$ complex 2a with air oxygen (Figure 1, curve 2) can be assigned to seco-porphyrazine $\mathbf{3 a}$ and pyraziniporhyrazine $\mathbf{4 a}$, respectively.

The maximum of the fluorescence spectrum for $\mathbf{4 b}$ is located at $734 \mathrm{~nm}$ (Figure 4, curve 3). The value of the Stock's shift $(21 \mathrm{~nm})$ is larger than it was obtained for phenyl substituted 1,2,5-selanadiazoloporphyrazine 1b (9 $\mathrm{nm}) .^{[12]}$ The fluorescence quantum yield for $\mathbf{4 b}$ is only $3.6 \%$. This might be connected with predominant non-radiative deactivation of the excited states, as is often the case for low-symmetry porphyrazines with efficient singlet oxygen generation ability. ${ }^{[5]}$

In summary, we have observed formation of the first representative of pyraziniporphyrazine - the novel type of aromatic porphyrazine analogues. The presence of 6-amino-2pyrazinone fragment should be favorable for complementary

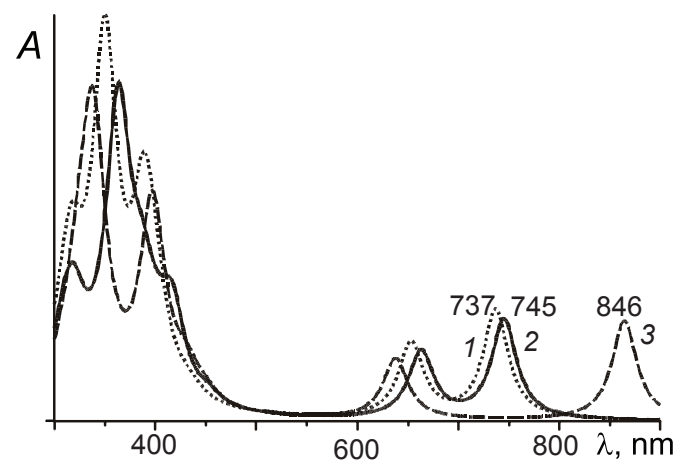

Figure 5. Theoretical UV-Vis spectra of phenyl substituted porphyrazine (1), 4-amino-2-oxypyraziniporphyrazine (2) and seco-porphyrazinedicarboxamide (3) (ZINDO/S method). 
hydrogen bonding with biopolymers such as DNA and further study of these species might be interesting.

Acknowledgements. This work was supported by Russian Foundation for Basic Research (grant 13-03-0902a).

\section{References}

1. Bauer E., Ercolani C., Galli P., Popkova I., Stuzhin P.A. J. Porphyrins Phthalocyanines 1999, 3, 371-379.

2. Ul-Haq A., Stuzhin P.A. Macroheterocycles 2008, 1, 82-84.

3. Zhao M., Stern C., Barrett A.G.M., Hoffman B.M. Angew. Chem., Int. Ed. 2003, 42, 462-465.

4. Kozlov A.V., Stuzhin P.A. Zh. Org. Khim. 2013, 49, 928-935 (in Russ.) [Russ. J. Org. Chem. 2013, 49, 913921].

5. Montalban A.G., Lange S.J., Beall L.S., Mani N.S., Williams D.J., White A.J.P., Barrett A.G.M., Hoffman B.M. J. Org. Chem. 1997, 62, 9284-9289.
6. Stuzhin P.A., Pimkov I.V., Ul-Haq A., Ivanova S.S., Popkova I.A., Volkovich D.I., Kuzmitskii V.A., Donzello M.-P. Zh.Org. Khim. 2007, 43, 1848-1857 (in Russ.) [Russ. J. Org. Chem. 2007, 43, 1854-1863].

7. (a) Lash T.D. Synthesis of Novel Porphyrinoid Chromophores. In: The Porphyrin Handbook (Kadish K.M., Smith K.M., Guilard R., Eds), Amsterdam, Academic Press, 2000, 2, 125 199; (b) Lash T.D. Macroheterocycles 2008, 1, 9-20.

8. Rodriguez-Morgade M.S., Stuzhin P.A. J. Porphyrins Phthalocyanines 2004, 8, 1129-1165.

9. (a) Elvidge J.A., Golden J.H. J. Chem. Soc. 1957, 700; (b) Borodkin V.F. Zh. Obshch. Khim. 1960, 1547; (c) Bamfield P., Mack P.A. J. Chem. Soc. 1968, 1961.

10. Lash T.D., Chaney S.T., Richter D.T. J. Org. Chem. 1998, 63, 9076-9088.

11. Danilova E.A., Islyaikin M.K. In: Uspekhi Khimii Porphirinov [Advances in Porphyrin Chemistry] (Golubchikov O.A., Ed.), Vol. 4, St.-Petersburg: NII Khimii SPBGU, 2004, 356-375.

12. Solovyov K.N., Stuzhin P.A., Kuzmitsky V.A., Volkovich D.I., Knyukshto V.N., Borisevich E.A., Ul-Haque A. Macroheterocycles 2010, 3, 51-62. 